\title{
Pedagogy of Hate
}

Mike Neary, University of Lincoln

mneary@lincoln.ac.uk 


\section{Pedagogy of Hate}

'I hate you, God, I hate you as though You existed.' (Maurice Bendrix in The End of the Affair, by Graham Greene, Vintage Books, London 2004/1951 159).

'The criticism of religion is the prerequisite of all criticism' (Marx, A Contribution to the Critique of Hegel's - Philosophy of Right (1844)

'Pedagogy of Insurrection: from Resurrection to Revolution' is an attempt to restore political religion to the centre of debates about revolutionary social transformation, grounded in Marxist-humanism and Christian socialism, with Jesus as the charismatic central figure. Jesus is not the only charismatic figure in the book, which includes Karl Marx, Paula Allman, St Gemma Galgani, Che Guevara, Paulo Freire, Hugo Chavez, Simone Weil, along with Beat poets, jazz musicians, hip hop rappers, novelists, Pope Francis and, of course, the author himself, Peter McLaren. The book is a showcase for McLaren to demonstrate the full range of his writing and thinking through the vehicle of revolutionary critical pedagogy.

This is a big, bold, brave and courageous book, taking sides with the poor and the dispossessed in an era of global civil war (Kurz 2014, Neary 2016). The book has a writerly sensibility, with the chapters arranged as a sort of random cut up montage, after William Burroughs, and is full of dramatic rhetorical flourishes with, at one point, figures representing the ghosts of former teachers raging against capitalists and right-wing politicians (McLaren 2015 391). The book begins with a foreword by E San Juan and a Preface by Michael Peters, followed by a chapter, Out of the Rubble Staking a Claim, where McLaren sets out his theoretical framework, then comes chapters on Jesus, Paulo Freire, Fidel Castro and Che Guevara, more chapters on Revolutionary Critical Pedagogy, Critical Ecopedagogy, Education as Class Warfare and Radical Negativity with a focus on music education for social justice; the final chapter is on Critical Rage Pedagogy. The book ends with an afterword by Lilia D Monzo and a section About the Author. 
Peter McLaren is a key figure in the development of revolutionary critical pedagogy. In this paper I engage critically with some of the core themes of this book: historical Jesus, the dialectic of love and hate, cognition and consciousness, capitalist abstraction and revolutionary theory. I want to avoid the type of hagiography that sometimes accompanies McLaren's work. There are examples in the opening sections, according him mystical powers: 'While of his age, he also transcends it' (Peters xxiv); and speaking about the book 'as a testimony to an examined life in the service of humanity' (Juan Jr xv). This impression of saintliness is not helped when McLaren claims to know that agnostics and atheists 'hunger... for a spiritual connection to that which speaks to us outside of ourselves' (43).

The book is at its best when it considers the nature of 'cosmic intelligence' (McLaren 2015 396), suggesting a sense of order amenable to human reason beyond the 'social universe' (313), and at its worst when it claims that God is 'unknowable' (403), as if being resigned to ignorance can ever be part of a revolutionary project.

The book, to its credit, is full of 'Marxist shit' (7). McLaren knows enough about Marxism to give top billing to Marx's theory of value and the need to abolish capitalism, but his commitment to value theory is undermined by his attachment to a number of other Marxisms, all of which drain Marx of its revolutionary intent (Anderson 1976). The use of Gramsci's concept of the hegemonic and the counter-hegemonic (154), gives too much to the idea that capital is a discursive ideology and Althusser's 'ideological state apparatuses' (19) fixes Marxism as a form of sociological structural functionalism (Clarke 1980), both of which are a long way from critical social theory. This is further devalued by his commitment to the liberal concept of equality, as if it was ever anything more than a bourgeois concept derived from imperatives of the capitalist markets (Pashukanis 1978, Mieville 2005).This surfeit of subversive phraseology might work as a rhetorical device, but undermines any scholarly exegesis of Marx's revolutionary theory. There are consequences for McLaren's claim to be both 'multiperspectival and 'dialectical' (McLaren 2015 312), limiting his capacity to sustain a critical critique. I am not suggesting a dogmatic Marxism, but a more systematic exegesis of Marx's work is required if we are to follow the prompting of one of McLaren's inspirations and rethink 'the meaning of his (Marx's) legacy for the realities of our times' (Hudis 2012 215).

McLaren writes about the crisis of capitalism (McLaren 2015 373), with suggestions for how this crisis might be managed and alleviated, e.g., by creating cooperatives and learning from 
anti-colonial and indigenous struggles in Latin America and elsewhere, based on the notions of Buen Vivir ( 93) and Pachamama (93), including struggles alongside non-humans (35). What is missing from his work is a theory of crisis: a sense of how 'the juggernaut' (302) of capitalism is prone to self-destructive dynamic tendencies is not considered. The world might be on the point of destruction, but there is no sense that Capital, following the logic of its own anachronistic capabilities, has reached a stage where its strategies for extracting surplus value have become exhausted, so that neoliberalism and even Capital have lost the capacity for expansive valorisation (Postone 1993, Kurz 2014). This leaves a dominant capital to be undermined by, as McLaren puts it, the '"onto-creative process of becoming fully human...' (McLaren 2015 12,) through uncovering 'Jesus' message of love and justice' so as to 'integrate this message into the field of revolutionary critical pedagogy...bringing about an alternative to value production, and in so doing, participating in our own redemption' (13). Invoking a theory of crisis is not a matter of choosing sides between objective and subjective interpretations of the value form, a rather crude formulation set out by Hudis in the book from which McLaren draws much inspiration (Hudis 2012), but a recognition of the need for a full scale reappraisal of Marx's notion of radical subjectivity and objectivity. This reappraisal has been ongoing since the 1960s through Adorno and his antecedents, referred to as 'the new reading of Marx', Wertkritik, Open Marxism and Communisation (Neary 2017). There is no account of this reappraisal in Pedagogy of Insurrection, a significant omission for a book about revolutionary Marxism.

McLaren seeks to recover the historical Jesus as the source of revolutionary charisma, based closely on the work of Jose Porfirio Miranda, the Marxist Jesuit theologian, as the basis for Christian communism. McLaren is clear that the Kingdom of God is not an apocalyptic event, but is to be achieved now 'here on earth... made possible by the grace of God' (McLaren 2015 105). Jesus is the true God grounded in social justice (109). God is not unassailable (109), but God does have supernatural powers, setting in motion 'the immanent and horizontal causality of human history itself' (Miranda 1974, quoted in McLaren 2015 117), rendering God omnipotent and interventionist. This is framed within an apophatic theology 'we know God through our admission that God is unknowable' (403), putting God outside the realm of human reason (117); but this negative metaphysical ontology is undermined by McLaren's affirmation of social justice, as if this most liberal principle could be the basis on which revolution is to be achieved (237).

There are problems basing revolution on the figure of the historical Jesus. Roland Boer in recent comprehensive work on Marxism and Theology has it that 'the words of Jesus, if not 
his life as a whole, are virtually impossible to recover. That he existed is generally, although not universally, admitted. What he said and did has been the subject of intense and ongoing quests for the historical Jesus, with no assured results' (Boer 2014 151). Boer points out that 'the Bible contains texts that are both reactionary and revolutionary' (2014 145). And 'it is impossible to know anything with certainty about the historical figure, Jesus of Nazareth' (2012 322).

Even if we are to take the gospel as gospel it is a bit of a push to present Jesus as a revolutionary communist given that his version of communism is only ever a communism of consumption rather than production. The Act of the Apostles 4: 34-5, widely credited by McLaren and others as the basis for Marx's definition of communism: 'from each according to his abilities, to each according to his needs' (McLaren 2015 107), says nothing about production and is entirely based on the sharing of resources: 'distribution was made unto every man according as he had need'. Boer maintains that 'Such a system actually maintains the status quo, for it requires some at least to continue generating wealth outside of the commune in order to keep redistributing goods' (Boer 2014 149). For this reason Rosa Luxemburg and Karl Kautsky ( Boer 2014 117-118) argue against Christian socialism as 'socialists demand a more fundamental change in the means of production' (118). Boer agrees that the history of the life of Jesus as the greatest story ever told is not without power as a revolutionary idea, but Christian communism is a ' classic political myth' (112), set alongside Marxism as the other great competing political myth (Boer 2013 319). There are plenty of references in Boer's work and elsewhere to dispute McLaren's representation of Marx as a closet Christian given his lifelong aversion to 'religious spookery' (Marx 1938 quoted in Toscano 2010 196).

I make no claim to be a biblical scholar but would want to make a methodological point, the recovery of Jesus as an historical figure is one thing, but to claim the historical Jesus as a transhistorical exemplar of universal values is another, and a complete anathema to any historical materialist methodology (Gunn 1981).

So how can we get beyond the idea of Christian socialism and Marxism as political myths, in a way that substantiates the claims for Marxism and understands the significant nature of religious spirituality as a dominant force in contemporary life and something more than a mental aberration? The answer can be found in Marx's critique of the critique of religion and, more generally, in his theory of abstraction (Toscano 2010, Toscano 2010a). Initially, following Feuerbach, Marx argued that God is the power of humanity in an alienated form, as 
an example of false consciousness, to support the subordination of populations by the clergy, religious institutions and other authoritarian political regimes. In later work Marx argues that alienation is not the result of a mental abstraction but is substantiated by the abstraction of labour: a social phenomenon, revealed as an historical and material entity operating like a force of nature in the world of time and space. The epitome of this process of capitalist abstraction is Money as the supreme form of social power (Clarke 1988). The suprasensual aspect of Money provides the intellectual space for the logical creation of a God in the form of a transcendental power without acknowledging its material social substance. God, like Money, is a real abstraction (Toscano 2005). Money is the materialised representative on earth of Capital, which exists as an automatic historical subject without an ego or a consciousness (Postone 1993 77).

The basis for Marx' theory of abstraction is set out in the first chapter of Capital Volume 1 where he establishes the commodity form as the organising principle for capitalist civilisation (Lukacs 1971, Postone 1993). The commodity form is the unity of the determinations of value: use and exchange, where the concrete utility of a commodity is overwhelmed by the imperative of capitalist exchange as part of an expansive cycle for the production of surplus value. Marx's main contribution to social science is to reveal the substance of value and its expansionary capacity as abstract labour, which acts like an impersonal form of social domination. The abstraction of labour (or value in motion) provides the basis for the social relations of production in capitalist society: the imposition of waged work, along with its dynamic and measure (socially necessary labour time) and logic for antagonisms (class struggle). This social process takes place without the need for Capital's characters to be aware of its real nature, while playing central roles in the organisation of manufacture (capitalists) as exploited labour (workers) and as the actors by which the exchange value of commodities is realised (consumers). Money has its own roles to play, not only as the universal form of exchange value, but the instrument through which the expansionary logic of the capitalist universe is maintained. In this sense Money might be likened to a sort of transcendental subject (Sohn-Rethel 1978). This is much more than an economic system; but, rather, a social synthetic system or web or life dominated by the logic of abstraction (Adorno 1962, Neary 2017). It really is the case that 'In capitalist society abstraction swamps rationality' (Kay and Mott 1982). This recovery of Marx as a theory of abstraction has been developed to include a Marxist theory of money and the state (Clarke 1991), history and time (Postone 1993) as a critique of the critique of religion (Toscano 2010) and even as a materialist theory of cognition (Sohn-Rethel 1978). 
McLaren is interested in cognition and its relationship to revolutionary critical pedagogy. Enjoined with 'religious pilgrims on a spiritual path...we have tried to make our own consciousness the object of our thought. We have tried to bolster our potential to think about thought itself' (McLaren 2015 54). McLaren does this thinking about thinking in relation to notions of abstract and concrete action. He cautions against the disconnected concept of abstract utopian praxis, which 'remains at the metaphysical level, locked into the beatific hinterlands of the imagination' in favour of concrete utopia praxis, as 'the creative practice of human beings living in the messy web of capitalist social relations - in the here and now - to overcome and transform the conditions of unfreedom' (31). The revolutionary project for McLaren and the basis for his revolutionary critical pedagogy is to ground the metaphysical in the concrete ( 31) 'by helping abstract thought lead to practice' (29) to create what he calls 'critical consciousness' (29) as the outcome of struggle and 'the bedrock of revolutionary critical pedagogy's politics of solidarity and commitment' (30).

This is very different from Marx's theory of abstraction and the way in which it has been elaborated by Alfred Sohn -Rethel in his book 'Intellectual and Manual Labour: a Critique of Epistemology' (1978), for whom there is no disconnection between abstract thinking and concrete action. For Sohn-Rethel 'abstraction is [not] the exclusive privilege of thought' (Jappe 2013 7) but a real process of abstraction in space and time that provides the social process out of which cognition itself is derived (Jappe 2013). In other words: 'the faculty of abstract thinking is not a given, a prius, as the idealistic conception of thought has always claimed, but is the result of real abstractions in the production and reproduction of human life' (Jappe 4). Sohn-Rethel traces the development of abstract thinking, including mathematics and physics, through the historical process of exchange relations culminating in capitalist exchange as its most generic form. Critics have pointed out Sohn-Rethel's over reliance on exchange rather than abstract labour, but the power of his exposition means it remains a significant contribution to the development of Marxist social theory (Jappe 20, Postone 1993).

The political consequences of Marx's theory of abstraction are clear. Revolution is not the recovery of humanity through a radical subjectivity by a process of transcendence, as McLaren suggests; rather revolution is refusal of transcendentalism, the dissolution of the social relation out of which real abstractions are derived, including the concept of humanity. Humanity is a capitalist abstraction: understanding 'man in the abstract' (Toscano 2010189 from Capital Vol 1 172), equivalent, homogeneous, indifferent, where the dynamic character of abstract labour, creativity, is expressed as if it were an essential aspect of human life ( 
Kurz 2007). There can be no surprise that Christianity is the most fitting form of religion in capitalist civilisation (Toscano 189): 'one man in the abstract is worth just as much or as little as the next man' (Marx Vol 3 448, Toscano 2010 190). Capitalism and the commodity form with all of its 'metaphysical subtleties and theological niceties' is the basis of transcendental thought (Neary 2002). Revolutionary politics is not then the recovery of a 'dehumanised humanity' (26), but the overcoming of ourselves: humanity, as both a form of value as well as creators of value: 'we cease to constitute value, so it ceases to constitute us' (Endnotes 2010). This abolition of capitalist life is undertaken while establishing another form of social wealth, based on the principle of abundance (Kay and Mott 1982, Postone 1993), or lifeenhancing life. It is to our advantage that the principle of life-enhancing life is already immanent within the capitalist web of life (Moore 2015).

What is lacking in terms of theoretical development in McLaren's work is partially compensated by his righteous anger expressed in the book as critical rage pedagogy. The chapter on critical rage grounded in absolute negativity is one of the most powerful parts of the book, but, even so, its rage is an 'understatement' (McLaren 2015 394) as its negativity is not negative enough. McLaren, the dialectician, needs to substantiate his pedagogy of love, with a pedagogy of hate: not a personal, psychological or pathological hate, but a radical structural hate for what the world has become. Radical hate is the critical concept on which absolute negativity is based.

The Pedagogy of Insurrection already includes references to hate, usually as a malevolent force and, therefore, to be avoided, although McLaren does hate technology (290). Yet, in the chapter on Che Guevara, hate is given its voice as a principle of revolutionary struggle: 'Hatred is an element of struggle' (Zizek 2008172 211). McLaren at one point gives himself up to the logic of love-hate dialectics: 'Hatred can be the only proof that we love someone' (211). McLaren frames this discussion about hate around the concept of violence through a discussion of Walter Benjamin's notion of 'divine violence', as interpreted by Slavoz Zizek (2008). For McLaren divine violence is 'the refusal to compromise' and 'a violence that refuses a deeper meaning; it is the logic of rage, a refusal to normalise crimes against humanity, either by reconciliation or revenge' (McLaren 2015 211). McLaren follows Jesus, who chose the path of non-violence (215) in his view that 'all acts of violence generate forms of evil' (213) and that violence can never establish the Kingdom of God (215).

This discussion about violence and hate is compelling, but it is not what Benjamin means by divine violence (Benjamin 1986/1921). Benjamin divides political violence between the 
mythic and divine, the former is political and state-law creating ('bloody power over mere life for its own sake'), while the latter is proletarian and state-law destroying ('pure power over all life for the sake of the living') (Benjamin 1986 297). The capacity to distinguish between these two forms of violence depends on a pedagogical process of deep contemplative reflection, what Benjamin calls 'educative power'. Educative power is not an absolute principle, or objective assessment, or 'a criterion of judgment' like the commandment 'thou shalt not kill' (1986 298), but a 'guideline' for those who have to take responsibility for such activities. Educative power is 'critical, discriminating and decisive' (299-300), providing the conditions by which state power can be abolished and 'a new historical epoch... founded' (Hirvonen 2011 300). Educative power is then a type of 'radical doubt... [or]... fundamental critique' (Zacharia 2007). Divine violence does not promote mortal combat or any form of intervention, so, like Ghandi, might mean the withdrawal from political life (Zizek 2008). Zizek, thinking about his own profession, argues that sometimes it is better to do nothing, rather than engage in 'pseudo-activity... to mask the nothingness of what goes on... academics participate in meaningless debates... Sometimes doing nothing is the most violent thing to do' (2008: 183), and could involve 'withdrawing to a solitary place to learn, learn, learn' (7).

McLaren is right about many things, not least the need for a revolutionary theory and action that supports the abolition of capitalism understood through value form theory and radical love (McLaren 2015 370). However, radical love must include radical hate for the magic of dialectics to work. Not a personal or pathological hate, but a hate for capitalist civilisation; this is fundamental to the structure and meaning of absolute negativity. This radical dialectical framework demands radical action along the lines that McLaren suggests, including setting up cooperatives and learning from struggles against colonialism. But, given the nature of what is at stake, the radical love-hate dialectic must contain the element of radical doubt, sustained, not by the assurance of revolutionary critical pedagogy, but by the pedagogical framework of Benjamin's educative power. I want to extend educative power beyond Benjamin's realm of deep contemplation and fix it as a central part of Marx's methodology, as a form of critical practical reflexivity (Gunn 1989 6, Neary 2015). The key to critical practical reflexivity, and what takes it beyond McLaren's own version of self-reflection (McLaren 2015 47), is to engender a critical process which calls into question the validity of its own categories based on the historical material context out of which they have emerged. Marx has already supplied the template for money as the 'universal equivalent' and the supreme form of social power in Capital 1, and shown how other capitalist categories can be included in the analysis, including God and Humanity, as complementary forms of the value relation. It is only by fixing these categories, or real abstractions, in their actual social 
substance that they can be disabled of their social power and stripped of their authority. But more than that even, this framework allows us to uncover abstract thought itself as the outcome of a process of real abstraction. It is by extending the discussion to consider the nature of cognition that I would like to make use of McLaren's concept of 'cosmic intelligence' (McLaren 2015 396), not in the sense of an extraneous transcendental unknowable omnipotent power, but as the process through which we come to know ourselves in 'the universe as a whole' (Huxley 1927 135). This focus on the cosmic could be extended to include the study of other monotheistic religions, Islam and Judaism, whose deities also take the form of abstractions (Toscano 2010). Cosmic intelligence is not the promotion of science over religion but the application of critical practical reflexivity against the abstract assumptions of capitalist science, and particularly the separations between the humanities and the natural sciences, to create 'One Science' (Marx 1975 355, Neary 2016).The purpose of developing our cosmic intelligence is not the affirmation of humanity, the humanities and positivistic natural sciences along with other forms of religiosity based on the logic of capitalist abstractions, nor to restrict our revolutionary ambition within the confines of 'the unknowable'; but to declare ourselves, all of us and all of it, as an intrinsic part of an ordered universe, of life-enhancing life to be lived now and forever.

\section{$\underline{\text { References }}$}

Adorno, Theodor ( 962) Adorno 1962. Notes on Seminar on Marx. https://reificationofpersonsandpersonificationofthings.wordpress.com/2012/06/25/adorno1962-seminar-on-marxl

Anderson, Perry (1976) Considerations on Western Marxism. New Left Books:London.

Benjamin, Walter (1986) 'Critique of Violence', Reflections: Essays, Aphorisms, Autobiographical Writings. Trans. E. Jephcott. Schocken Books: New York, p 277 - 300 [1921].

Boer, Roland (2013) Criticism of Earth: on Marx, Engels and Theology, V. Chicago: Haymarket Books. 
Boer, Roland (2014) In the Vale of Tears: on Marxism and Theology IV. Chicago: Haymarket Books.

Clarke, Simon, Lovell, Terry, McDonnell, Robins, Kevin, Jeleniewski Seidler, Victor 9eds) (1980) Introduction. One Dimensional Marxism: Althusser and the Politics of Culture. Allison and Busby: London, p 5 -102.

Clarke, Simon (1991) The State Debate. London: Palgrave MacMillan.

Clarke, Simon (1988) Keynesianism, Monetarism and the Crisis of the State. Edward Elgar: Aldershot.

Endnotes 2 (2010) Communisation and the Value-Form: https://endnotes.org.uk/articles/4

Kay, Geoff and Mott, James (1982) Political Order and the Law of Labour. MacMillan

Kurz, Robert (2007) Grey is the Golden Tree of Life, Green is Theory:

https://libcom.org/library/grey-golden-tree-life-green-theory-robert-kurz

Kurz, Robert (2014) 'World Power and World Money: The Economic Function of the US Military Machine within Global Capitalism and the Background of the New Financial Crisis', in N. Larsen et al. (eds), Marxism and the Critique of Value. Chicago-Alberta: MCM Publishing.

Greene, Graham (2004) The End of the Affair. Vintage Books, London 2004/1951

Gunn, Richard (1981) Notes on Marxism and Religious Belief. David Stacey (ed) Is Christianity Credible? Epworth Press, 1981:http://www.thiswasnottheplan.com/wpcontent/uploads/2016/05/notes on marxism religious belief.pdf

Gunn, Richard (1989) Marxism and Philosophy: A Critique of Critical Realism. Capital and Class. Critical Realism and Critique of Philosophy. 37, p 1- 30.

Hirvonen, Ari (2011) 'The Politics of Revolt: On Benjamin and Critique of Law', Law Critique 22 (2). Available at http://www.researchgate.net/publication/226159745_The_Politic s_of_Revolt_On_Benjamin_and_Critique_of_Law. 
Hudis, Peter (2012) Marx's Concept of the Alternative to Capitalism. Netherlands and Boston: Brill

Huxley, Julian (1927) Religion with Revelation. London: Benn.

Jappe, Anselm (2013) Sohn -Rethel and the Origin of "Real Abstraction": A Critique of Production or a Critique of Circulation? Historical Materialism. 21 1, p. $3-14$.

Lukacs, Georg (1971) History and Class Consciousness: Studies in Marxist Dialectics. London: Merlin Press.

Miéville, China (2005) Between Equal Rights: A Marxist Theory of International Law, Leiden: Brill Publishers.

Miranda, Jose Porfirio (1974) Marx and the Bible: a Critique of the Philosophy of Oppression. New York: Orbis Books

Neary,Mike (2017) Teaching Marx: Interdisciplinary enquiry or Unity of the Sciences?: https://Nearymike.wordpress.com/2016/12/20/teaching-marx-in-anglophone-universitiesinterdisciplinary-enquiry-or-unity-of-the-sciences/

Neary, Mike (2017) Critique of Labour and Critical Theory. In A Handbook of Critical Theory and the Frankfurt School. (eds) Werner Bonefeld, Beverley Best, Nils Larson, Chris O'Kane. London: Sage.

Neary, Mike (2015) Marx as Revolutionary Science: An Introduction: https://nearymike.wordpress.com/2015/10/

Marx, Karl (1990) Capital: Critique of Political Economy. Volume 1. London: Penguin Classics

Marx, Karl, (1938) Critique of the Gotha Programme. International Publishers [1875]

Marx, Karl (1844) A Contribution to the Critique of Hegel's - Philosophy of Right: https://www.marxists.org/archive/marx/works/1843/critique-hpr/intro.htm 
Marx, Karl (1992) Economic and Philosophical Manuscripts. Early Writings. London: Penguin Classics.

Moore, Jason (2015) Capitalism and the Web of Life: Ecology and the Accumulation of Capital. London: Verso.

Postone, Moishe. (1993) Time, Labour and Social Domination: A Reinterpretation of Marx's Critical Theory. Cambridge: Cambridge University Press.

Pashukani, Evgeny (1978) Law and Marxism; A General Theory. Pluto: London.

Sohn-Rethel, Alfred (1989) Intellectual and Manual Labour: A Critique of Epistemology. Macmillan: London.

Toscano, Alberto (2010) Fanaticism: On the Uses of an Idea. London: Verso

Toscano, Alberto (2010b) Beyond Abstraction: Marx and the Critique of the Critique of Religion. Historical Materialism. 18 1, p. 3-29.

Toscano, Alberto (2005) Real Abstraction Revisited: Of Coins, Commodities and Cognitive Capitalism: https://www2.le.ac.uk/departments/management/documents/research/researchunits/cppe/seminar-pdfs/2005/toscano.pdf

Zacharias, Robert (2007) Any Yet: Derrida on Benjamin's Divine Violence. Mosaic, p. 103116.

Žižek, Slavoj (2009) Violence: Six Sideways Reflections. London: Profile Books.

Lincoln

March 2017 